\title{
THE CONCEPT OF LANGUAGE LEARNING IN BEHAVIORISM PERSPECTIVE
}

\author{
Khoiru Rakhman Abidin \\ English Department of Education Faculty \\ STAIN Salatiga \\ Khoirurakhmanabidin@gmail.com
}

\begin{abstract}
The aims of the study are (1) the concepts of language learning in behaviorism perspective, (2) the relation between language and learning in behaviorism perspective, (3) the influence of behaviorism in language learning. This is a descriptive qualitative study. The results showed that (1) behaviorism theories of languages also give good contribution in language learning process that describes a child can learn language from their environments, (2) behaviorism perspective defines as change of behavior through experience, it means human learn something from their environments, (3) human uses language for communication in the world and he also spreads his culture with his language so human gets knowledge of language through learning.
\end{abstract}

Keywords: Behaviorism, Language, Learning, Language Learning

\begin{abstract}
Abstrak
Tujuan dari studi ini adalah untuk meneliti ( 1 ) konsep pembelajaran bahasa dalam perspektif behaviorisme, ( 2 ) hubungan antara bahasa dan pembelajaran dalam perspektif behaviorisme , ( 3 ) pengaruh behaviorisme dalam pembelajaran bahasa. Penelitian ini merupakan penelitian deskriptif kualitatif . Hasil penelitian menunjukkan bahwa ( 1 ) teori behaviorisme tentang bahasa juga memberikan kontribusi yang baik dalam proses pembelajaran bahasa yang dimana seorang anak bisa belajar bahasa dari lingkungan mereka, ( 2 ) perspektif behaviorisme didefinisikan sebagai perubahan perilaku melalui pengalaman. Itu berarti bahwa manusia belajar sesuatu dari lingkungan mereka, ( 3 ) manusia menggunakan bahasa untuk berkomunikasi dan berbagi dalam hal budaya melalui bahasa sehingga manusia mendapatkan pengetahuan tentang bahasa melalui pembelajaran.
\end{abstract}

Kata Kunci : Behaviorisme, Bahasa, Belajar, Pembelajaran Bahasa 


\section{Introduction}

Language is important for communication in this world. We need language to communicate each other. We learn language since we were children until we became man. Language is a system to communicate from one aspect to another .It. is intimately tied to man's feeling activity. It is bound up with nationality, religion and feeling. It is used for work, worship, etc (Lado Robert, 1964:11).In linguistic, language is an arbitrary system of speech sounds or sequences of speech sounds which can be used in interpersonal communication by an aggregation of human beings and rather exhaustively catalogs things, process and event in human environment (Ramelan, 1984:15).

Learning is basic to human existence and fundamental to education. It is the base of operation for the study of psychology and to understand the human mind. Indeed no other topic in psychology has been as thoroughly researched as that of learning. The problem of learning has concerned students of human behavior from the beginning and is has been central concern with the issues and problems of learning. In Thorndike's behaviorism there are four laws of learning: law of readiness, law of exercise, law of effect, law of associative shifting (George, 1980).

In behaviorism perspective, learning is as habit of information. It means learning is mechanical process as habit of information and proceeds by means of the frequent reinforcement of stimulus and response. The first successful assault on behaviorist theory came from Chomsky. He called behaviorism on the question of how the mind was able to transfer what was learnt in one stimulus- response sequence to other novel situations. There was a vague concept of generalization in behaviorist theory, but this always stated 
over and never explained. Chomsky dismissed the generalization idea as unworkable, because it simply could not explain how from a finite range of experience, the human mind was able to cope with infinite range of possible situation (Tom, 1987:54).

Behaviorism is a trend of psychology which studies the behaviorism theories. The behaviorism derived from positivism philosophy which is proposed by august comte. Behaviorism is particularly concerned with epistemology, that is, with understanding the nature and limits of knowledge. Behavior is a function of genetic endowment, as evolution selects certain characteristic over the lifetime of the species. (2003)

In this statement the writer formulates the problems as the following:

1. How is the concepts of language learning in behaviorism perspective?

2. How is the relation between language and learning in behaviorism perspective?

3. How is the influence of behaviorism in language learning?

\section{Research Methodology}

This paper will conduct library research in order to get some data in this study. The research method, which will be used by writer, as the following.

1. Method of collecting data about language and learning in behaviorism perspective, the writer uses library research to study the writing sources, which is published.

a. Secondary data source 
The secondary data source is the data, which support and complete the primary data, for an example book about language, learning and behaviorism book theory such as :

- Peter hariot, 1970, An Introduction to the Psychology of Language, Mc Graw Hill, London.

- Gazda M George and Cousini J Raymond, 1980, Theory of learning a Comparative Approach, Peacock Publisher Inc.

- Lado Robert, 1964, Language Teaching A scientific Approach, Mc Graw Hill Inc, New York

- Ramelan, 1984, Introduction to Linguistic, IKIP, Semarang

- Hutchinson Tom and Waters Alan, 1987, English for specific Purpose. Cambridge University Press, London

2. The methods of analyzing data

a. Descriptive method

The descriptive method means it describes all variable of research systematically. (Arikunto,1994:25)

b. This is still a general description to understand this research easily; the writer uses the books, which are appropriate with the research. It means the writer looks for books, which have relation with the research in this study.

3. Method of study

To find the answer of problem above the writer uses:

a. Thematic method

It means that the writer uses term when collect books, which are related to the theme. The writer formulates the problems, which will be studied.

b. Non-statistic analysis method (Qualitative Method). 
This analysis is done by reading and collecting data (Warsito, 1993: 23)

\section{Discussion}

There are some theories of learning language, i.e.:

\section{Behaviorism Theories}

In behaviorism theories there are several theories of learning such as:

a. Thorndike connectionism

Thorndike explained that, learning as trial and error. Trial is defined by length of time ( a number of errors) involved in a single reacing of the goal. He says, language cannot learn by trial and error theories. According to Thorndike there are four laws of learning:

1) Law of readiness

Law of readiness characterizes many of the circumstances under which a learner tends to be satisfied or annoyed.

2) Law of exercise

Law of exercise has two forms: the use of a connection will increase it strength. The diffuse of a connection leads to it is weakening or forgetting.

3) Law of Effect

Throndike interpreted a number of experiments as showing that the effects of reward and punishment were not equal and opposite as had been implied in the earlier statements on the effects of satisfiers and annoyers.

4) Law of associative shifting

In law of associative shifting Thorndike explained that, if a response can be kept intact through a series of gradual change in 
the stimulating situation, it may finally be given to a totally new stimulus.

\section{Nativism theories}

The nativism position holds that much of the capacity for learning and memory in both human and nonhuman is innate. It is part of genetic makeup of species and it is relatively independent of any particular experience that may occur after birth.

3. Chomsky's theory:

Good points:

a. Explains why language is learned relatively quickly

b. Explains how language is learnt despite poverty of the stimulus

Bad Points:

a. Very little evidence for adult like grammatical knowledge in young children

b. Young children make errors Chomsky would not predict

c. Cannot explain why children make grammatical errors even after extensive language exposure. (Chomsky: 2003)

\section{Behaviorism concepts of learning language}

Learning in behaviorism perspectives is divined as change in behavior due to experiences. Behaviorist finds several theories of learning, which influences the learning concept. Those are: classical conditioning, Thorndike connectionism and operant conditioning. The concept of learning has been channeled into three main streams as: conditioning, verbal learning, trial and error.

In behaviorism concept of learning, there are two periods: 
1. Classical behaviorism

Ivan Pavlov the pioneer of classical conditioning theory is doing experiments about the relation between stimulus and response. Pavlov researched on her dogs. He find that, dog gets stimuli from food and it also response it, with it is sense. Pavlov found that stimuli from food and it also responses it, with it sense. Pavlov found that stimuli make response. Although the experiments were performed on dogs, it is assumed that the process applies to man behavior. In language learning, only some parts might be explained by conditioning, for example: the arbitrary connection between their meanings. (George 1980: 4)

2. Neo behaviorism

Skinner finds the operant theory; it takes behavior, as it fundamental subject factor in learning process. Skinner researched on application of operant theory to human behavior. Skinner divides two kinds of responses in learning process. Those are respondents and operant; both of them have bound up relation and influence each other.

In Thorndike connectionism theories, learning is defined as trial and error. Trial is defined by length time involved in a single reaching of the goal.

Thorndike finds four laws of learning:
a. Law of readiness
b. Law of exercise
c. Law of effect
d. Law of associative shifting (Ernest, 1988: 114) 


\section{Behaviorism Concept of Language}

Behaviorist says that, people acquire language through language acquisition, because the most fundamental concept of language is language acquisition. According to behaviorist, humans are born in this world without any perception of language or tabularasa and he learning language from his environment. Language is fundamental part of human behavior and behaviorist has examined it such and sought to formulate consistent theoris of first acquisition. (Robert, 1964: 23)

Implication of Behaviorism of Learning and Language in Language Learning

Behaviorism learning theoris gives several implications in language learning process. Those are as follows:

1. Shaping

Teacher usually teaches simple behavior in the scholl, they do not teach behavior in teaching learning process. The complex behavior can be taught through shaping or successive approximations. Shaping refers to procedure in which successive approximation to some terminal behavior is reinforced. This process begins with the purposes of study, assignment analysis, students activities and response to the reinforcement. (Blankship, 1981: 227)

Frazner states five steps of student's behavior in learning process:
a. Come on time in the class
b. Actives in learning process
c. Show the good result of the test
d. Doing theirs homework
e. Complement 
2. Modelling methods

Modelling is the one types of learning on behavior. The language teacher often uses this method in language learning process. A learner imitates the teacher's behavior in learning process, ex: an English teacher reads English book regularly in the class in language learning process. Teacher is model for students in learning process then, the students will imitate behavior. The students will also read regularly in the class like their teacher.

3. Reward and punishment theories

In the learning process a teacher often gives a punishment to their students because of students guiltiest. This punishment should be applied in wise ways in the class. The students often get reward when they get good achievements in learning process. This method is based on Skinner theory of reward and punishment. In teaching learning process students usually get a difficult with foreign language subject, so, they often get punishment from their teacher. Reward and punishment are one of the implications of Skinner behaviorism theories in teaching learning process especially in language learning.

4. Programmed learning

Programmed learning is the application of the principles of operant conditioning. This learning process happens when the students get assignment from the teacher and they do it. In language learning process the teacher give assignment to the students to read the story in their foreign language book they will do it.

Programmed learning has four purposes such as:

a. Summarize the learning material

b. To force the students read the learning materials

c. Give the result of learning directly to the teacher 
d. Use effective time in learning

5. Assignment or Task

According behaviorist there are components of learning those are:

a. Purposes and study in behavioral

b. Divides task into sub task

c. Determine the relation between sub task

d. Determine material and procedures of sub task

e. Giving feedback in the end of sub task (Gazda:22)

These learning component means the students always do the task and divide it into sub task. In language learning process the students always practice the task from language teacher, then, the result will be analyze by the teacher. (Ibid: 206)

The last implication of behaviorism of language and learning in language learning is language acquisition theories. The behaviorist has found the language acquisition theories and these theories has been applied until today. Behaviorist says that human born without any perception of language or it is called tabula rasa and human learns language from their environments.

The language is form of culture and human uses the language as means of communicating. It means that human communicates with their own language. The behaviorism theories of learning give good implication in teaching learning especially in language learning process.

Chomsky expressed this in a much stronger form. He believed that the input children receive was degenerated and an insufficient basis for language learning. In this theory of language acquisition is explained on the basis assuming that children have innate language learning capacities that enable them to acquire language despite the impoverished input. Working in this 
same framework Pinker in his 1994 publication proposed that the language is an instinct that has evolved out of adaption throughout the evolution of man. The innate linguistic capacities contain universal grammatical principles that are subsequently set according to the language-specific characteristics in the input.

According to Thorndike there are two implications of behaviorism in language learning. Those are Theoretical and Practical. In theoretical implication, the implication of behaviorism is based on the theory of learning in behaviorism. Thorndike stated that the four laws of learning gives good contribution in learning language. In practical implication, Thorndike stressed the importance of habits and procedures in learning especially in language learning process. (George: 22)

According to the Skinner the theoretical implications of operant theory creating an effective behavioral language, vocabulary and grammar such a language must allow behavioral phenomena to be coherently described. Among the useful aspect of the contemporary language of operant theory are the distinction between omission and elicitation of responses, the extension of this vocabulary discriminate the usage of response. A behavioral language may be particularly effective in extensions to verbal behavior. Speaking and writing are kinds of behavior, but vocabulary creates difficulties for a behavioral account. For example human speak using words. This vocabulary not only fails to distinguish spoken to written verbal behavior but also treats words as manipulable things rather than as kinds of responses. Verbal behavior has often been treated as if skinner derived all language from the stimulus - response associations of other varieties of behaviorism. (George: 169) 


\section{Conclusion}

The concepts of language learning in behaviorism perspectives based on the behaviorism theories of learning, which gives good contribution in teaching learning process. Behaviorism theories of languages also give good contribution in language learning process. With language acquisition a child can learn language from their environments.

The relation between language and learning in behaviorism perspectives has deep relation which influences each others. In behaviorism perspective learning defined as change of behavior through experience it means human learn something from their environments. Language in behaviorism perspective can be divided as several items those are:

a. Language as a system which includes: Phonetic, phonemic, phonology, syntactic, semantic

b. Language as inter-personal behavior

c. Language as skill behavior

These three items are the concept of language in behaviorism perspectives. Behaviorist has found the learning theories and language theories both of them have a relation especially in language learning. Human acquires language with a learning a language. Language is form of culture. Human uses language for communication in the world and they also spread their culture with their language. Human get knowledge of language through learning.

\section{References}

Arikunto Suharsimi. 1994.Metodologi Pendidikaan. Rineka Cipta: Jakarta. 
Chomsky, 1987, The Role of Language Acquisition, www. Philosophyoflangauge.com

Chomsky, 2003, Natives Theories of Learning, www.Theoryoflearning.com

Gazda M George and Corsisi J Raymond, 1980, Theories of Learning a Comparative Approaches, Peacock publisher Inc: Itasca Ilinois

Gordon H Bower and Ernest, 1988, Theory of Learning, Prentice hall Inc, Englewood cliff: London

Hermawan Warsito, 1993, Pengantar Metode Penelitian, Rineka cipta: Bandung

Lado Robert, 1969, Language Teaching a Scientific Approach, Mc Graw hill: New York 